\title{
Difficulties and Perspectives of Parametrical Conception of Language
}

\author{
A.V. Paribok ${ }^{1}$, R.V. Pskhu ${ }^{2 *}$, G.V. Zashchitina ${ }^{3}$, \\ L.G. Roman ${ }^{2}$, N.N. Danilova ${ }^{3}$ \\ ${ }^{1}$ Saint-Petersburg State University (SPbSU), \\ 7/9, University embankment, St. Petersburg, 199034, Russian Federation \\ ${ }^{2}$ Peoples' Friendship University of Russia (RUDN University), \\ 6, Miklukho-Maklaya St., Moscow, 117198, Russian Federation \\ ${ }^{3}$ Moscow State Linguistic University (MSLU), \\ 11, Tverskaya St., Moscow, 125993, Russian Federation \\ *pskhu-rv@rudn.ru
}

\begin{abstract}
The article looks into the issues, outlined in M. Baker's The Atoms of Language: The Mind's Hidden Rules of Grammar. This work is notable for the parametric theory of the languages, set out in it, according to which languages are different, nevertheless retaining the ability to be compared. That can be further supported by the assertion that the differences among languages are determined by "a smallish number of discreet elements, called parameters."What is more, the diversity of language reveals a certain regularity, very much resembling that of Mendeleev's periodic table of chemical elements. Our research team of professional linguists and philosophers put this claim to a critical analysis, the results of which are featured in this article. One of the major ones among them is the supposition that Baker, in accordance with the traditions of Chomsky generative linguistics, turns temporal continuums into special relations. He did that without discussing the consequences of such move, which made it impossible to develop the psychological and linguistic aspect of the subject raised by him.
\end{abstract}

Keywords: linguistics, philosophy of language, parametric theory of language, language, language parameter, generative linguistics, language thinking

Funding and Acknowledgement of Sources. Статья подготовлена при поддержке гранта РФФИ № 20-011-00479.

\section{Article history:}

The article was submitted on 18.01.2021

The article was accepted on 29.03.2021

(C) Paribok A.V., Pskhu R.V., Zashchitina G.V., Roman L.I., Danilova N.N., 2021

(c) (i) This work is licensed under a Creative Commons Attribution 4.0 International License https://creativecommons.org/licenses/by/4.0/ 
For citation: Paribok A.V., Pskhu R.V., Zashchitina G.V., Roman L.I., Danilova N.N. Difficulties and Perspectives of Parametrical Conception of Language. RUDN Journal of Philosophy. 2021;25(2):340-348. (In Russian). DOI: 10.22363/2313-2302-2021-252-340-348

On the basis of linguistic analysis, set out by M. Baker in his book The Atoms of Language: The Mind's Hidden Rules of Grammar, one can outline some conclusions, concerning the peculiarities of language parameters and their correlation with a human mind.

There are some parameters, which are not usually typical of the bulk of modern Western languages, but at the same time, characteristic of more ancient ones or even modern, but primitive cultures. These differences become more evident in the parameters of polysynthesis, and are observed through syntactical differences, such as, for instance, the word order in a sentence. If we assume that speech is the result of a thought being verbalized, and consequently, language is a form of human thinking, his way of viewing the world, then these differences can suggest certain conclusions.

The way a person of some primitive culture views the world is based on a way of thinking, that is more poetic and determined by myths or even religion. But if we take a person belongs to a modern western culture, his or her way of thinking can be classified as scientifically slanted, with all the due characteristics attached to that. These are a necessity for following the formal logic, rationalism, an analytical component, etc.

Thus, if we take English as an example of a fusional and analytical language, and as a representative of a modern language group, we will see some peculiarities, typical of a scientific, mechanistic way of looking at the world by its speaker.

We cannot see any examples of a conventional polysynthesis parameter $^{1}$ in English. This characteristic can be defined as a feature requiring that a few morphemes and meanings should merge in one grammatical forms, which represents a tendency for integrity, that is so akin to synthetic way of perceiving and understanding the world. The scientific approach is based on the analysis, breaking and separation, singling out the main and the subordinate. The synthetic trend, on the contrary, is represented at a comparatively primitive stage by mythology, and as fully developed in philosophy, as e. g. in Ancient Greek and in Sanskrit. That might be the reason why we can come across extremely lengthy forms in the languages of primitive cultures. To give an example of such language, Baker refers to Mogavk [1]:

Washakotya 'tawitsherahetkvhta'se'

"He has made a thing to be put on (that is clothes) that is ugly for her."

\footnotetext{
${ }^{1}$ We can come across cases of incorporation in English. Such is the case of words like 'babysit', or 'breastfeed', but it does not give us any reason to consider English a polysynthetic language, as such examples are rare, and the incorporation factor is not a primary or basic one in English.
} 
Talking of the nature of polysynthetic languages, as compared with fusional ones, Manuel Mager et al. also point to a fact, that, translating from a polysynthetic language to a fusional one faces difficulties; a significant number of morphemes can get lost because polysynthetic languages have structures that are different from those of fusional languages. A main difference between the fusional and the polysynthetic languages lays at the syntax level of a sentence [2].

There is no static in polysynthetic languages, nor are any rigid rules or limits, the structure appears to be free and unstable, which allows one to speak of some chaos, that is conditioned in its wholeness, rather than a strictly regulated reductionism.

We can see some traces of polysynthesis in some Western languages, such as German, but it can hardly be observed in day-to-day use, more likely in philosophical literature. It is there that German idealism ties to break through the conventional frames and aspires to represent the integrity.

There is little doubt that we can sharply outline two language groups: the group of modern Western languages and languages of primitive cultures, yet one can take notice of some common features.

Science speaks of facts, what is more, those facts, that are given in our experience. Science is limited by the proved findings. English, as a representative of a modern Western person is a language of facts. One sentence is strictly limited by the frames of one, primary meaning. This is best illustrated by some syntactical peculiarities as, for example, the word order in a sentence in his book Baker singles out one such parameter as the parameter of the peak placement.

If we take Sanskrit, for example, and try to compare it with English, one would possibly see in this parameter the difference that exists between scientific way of thinking and that of philosophical or and poetic one.

Sanskrit possesses an open system of expressing meaning in a sentence. And it is often due to a verb, that is placed at the end of a sentence, that does not allow one to narrow down the meaning to a single point. You can grab the meaning of the sentence only after you have read it to the end, perceived the whole of it. That is just another example of the tendency to integrity, but it also points to some peculiarity of thinking that is aspiring towards an open array of meanings.

English uses pure facts, which speaks of a way of thinking, that is based on reductionism. We can easily catch the meaning of something after some word for word reading and translation. Science determines the nuclear of the meaning, which is not context depending. English is a language, in which independent facts, that make the nuclear of meanings, are joined according to strict rules and are not conditioned by each other. Here, if you take some facts out, the sentence will not collapse, it will become a little bit less complete from a technical point of view.

On the other hand, Sanskrit is an example of philosophical andlor poetic view of the world, where a person is not regulated by some limited facts, where we can see how integrity can be brought to mind, where everything is strictly conditioned, and one can never simply extract some part of the sentence without any risk of 
losing the grip of the meaning. For Sanskrit, word for word reading or translation seem to be not enough, as there is something more substantial present here.

Some drawbacks of this approach, which is so common American, can be put down to the popular character of the genre. According to the author, a true and acceptable factor is that linguistics, as a science, in rather same way as chemistry. The only difference is that the latter is way younger. Yet he often and willingly resorts to likening linguistics with the periodic table of chemical elements. That helps him to reveal himself as methodologically 'innocent' stickler of scientism. Linguistics, unlike chemistry, should not distract itself from a fundamental factor: the speech is the actual manifestation of mind and is aimed at it, the mind itself cannot be the object of the science, about which much was said and spelled out long ago, starting from Phénoménologie de la perception by Merleau-Ponty (1945) [3]. Baker's view also seems so similar to those nativist views of Chomsky, who held, that linguistic structure was part of our biological endowment, so that variation between languages was merely superficial, and that a single universal grammar underlay all languages beneath the surface. The nativist position, thus, holds that universals of cognition shape all languages. When languages do differ, they do so only superficially, and these differences do not affect how we think [4].

While discussing the syntactical rule of order the author uses spatial signs (graphs) and terms (left, right), which is generally accepted in generative linguistics. Yet according to this approach the temporal continuum, in which one thing follows the other, is substituted with a spatial juxtaposition. This approach relies heavily on the generally accepted and quite common habit of the western perceptual logics, which was defined by A.V. Smirnov for description of Arabic mind-set [5]. Basically 'the right' is said and thought after 'the left', and in case a sentence is fairly vague, thinking in a language is done in quite a different manner. This transition of temporal into the spatial is regarded by us not so much as neglected as more likely a definite factor, which in its turn may limit some further attempts at looking into the matter. Within the realm of linguistics, the abovementioned factor falls into the domain of psycholinguistics, but it might also matter a lot, in the general sense, in culture studies and philosophy. Indeed, the whole array of conventional sets of word-forms and utterances, often dictated by parametric decisions, undoubtedly correlate with the acceptable natural metaphysics of a certain language. In some cases, this metaphysics has managed to develop and reveal itself, for instance in national philosophical schools of thought or in certain cases of major philosophical decision-making. Before we go down to some illustrations, we would add one more parameter, which was mentioned by Baker, but too cursory and only partially. This word order in the nominal and verbal sentences (naturally, providing there is a clear distinction in a language that exists between these two types of sentences, which is often accounted for in the majority of cases). On the basis of purely combinatory factors, one can expect to see four cases.

1. Both types of sentences show the S-P order. Such are Ancient Greek, Latin, and the majority of modern European languages. 
2. In the nominal sentence we see the S-P order, where is in the verbal, on the contrary, we observe the P-S type. Such is the case in Arabic, Welsh and some other languages.

3. A reversed case when nominal sentence is based on the P-S pattern, and the verbal one - on the S-P type. Such is the case with Sanskrit.

4. No obviously registered variant of the general P-S order.

The first type served as the language basis for classical metaphysics formation, which accepts that a) there exist primarily entities in the world and b) the secondary character of their properties. The thought process then ran as follows: something is always said first, because this is what is present or exists initially, and then turns out as it is. E.g., the order of questions by Aristotle. First one asks if that is present $(\mathrm{S})$, and then what it is like (P). 2. The second type of order also proved to be a factor of formation of 'procedural' intuition according to the sense and logic in the Arabic language. It also contributed to the problem of telling entity from existence, which was suggested by Arabic philosophy and only later was accepted by the Western thought. 3. The third case prevented the appearance in Indian philosophy of a similar equivalent, practiced in Western syllogistic, grounded on the difference between notions and reasoning. Instead of that, Indians worked out a theory of an orderly transition of the mind from one content to another. That is so unusual for a Western mind, that until now it has been interpreted by European scholars as somewhat faulty variant of Syllogism. It is noteworthy that Biruni, who reasoned in Arabic manner (Type 2), in his work 'India' noted that, what he called "pervertedness" of Indian mind (contrary Type 3), and that was a tendency to understand and to think "in a backward fashion."

Speculating over the universal character of S-P order, S. Potter (also referring to Aristotle) questions the fact that this sentence structure has its foundation in reality. And if so, we, then, might expect to find it in all the languages of the world. Potter then maintains, that if that was the case we would probably have to speak of that S-P bipartition as of some universal characteristic. In accordance with that, he also stresses, that predication is, of course, common to all Indo-European languages, and it definitely forms the basis of the sentence structure of many other languages and reflects the normal attitude of the speaker to what he is saying, but that it is not necessarily universal [6].

It is yet noteworthy, that that in his other work Baker also distinguishes "headmarking" languages from "dependent-marking" ones. The first type of languages, in the most cases, has a "head-final structure (SOV)" or a free word order, while the second type exhibits a head-initial structure (SVO or VSO) [7].

But we must bear in mind that not all polysynthetic languages have the headfinal structure. While English prefers an SVO-structure, in German different orders are possible: we can find the SOV-structure only in subordinate sentences, while in main sentences we can have either an SVO-structure, or an OVS-structure for emphasis. In contrast, in such polysynthetic language as, for example, Nahuatl the OVS-structure is unacceptable [8]. 
We would like to introduce one more difference, which is so vital for psycholinguistics and philosophy of thinking in a language. A lexeme or a word form, on the one hand, and a syntactical structure (phrase), on the other, differ in terms of the property, characteristic of the rest and the movement of the mind, respectively. When perceiving a word form or a lexeme, a listener or a reader's mind identifies it and then for a very short span of time keeps still, without making any attempt at thinking. The same case can be observed, when in the process of making an utterance, a relevant item is drawn as ready-made from the memory only to be inserted in a constructed phrase. On the contrary, coining as well as understanding of the syntactical structure requires some transition of mind from one language notion to another. The differences of syntactical orders in languages also prove to be a different arrangement of conventional movements of mind from one content to another. This factor can explain a greater peculiar difficulty in language acquisition by native speakers of such languages, as English or Russian, the syntax of language similar to Japanese, Hindi, or Turkish (as well as the other way).

Polysynthetic parameter, that is to say, the presence in a language of reproduced word forms for such ideas, which in other languages are constructed syntactically, undoubtedly an extremely valuable contribution to a variant of what a language does to formally set a lexeme and a phrase apart, and what it also does when it draws a borderline between a static state and a movement in thinking in a language. That may probably explain the challenge that a learner of polysynthetic languages inevitably comes face to face with.

Finally, one more illustration: the standard order that a language chooses for attributes and attributive elements in such cases as the place of an adjective to a noun ('sinee nebo' or 'nebo sinee' preposition or postposition of a prenominal genitive ('a leaf of a tree' versus 'tree's leaf'), a markable bias towards using prepositions or postpositions. The French language is very consistent in preferring the first alternative, thus it paves the way for the language thinking and philosophy to be more biased towards the claim of primary character of all entities, their real existence, of static intuition, which was so clearly defined by the authors of The Port-Royal Grammar. According to them, when it comes to the semantic level of the language, one can speak of solely one verb 'to be', whereas all the others verbal lexemes are merely short forms of this verb, used with different nominal items. Pierre speaks (Pierre parle) $=$ Pierre is speaking (Pierre est parlant). This classical approach could not be worked out or accepted by other languages that use another order of elements, such are Arabic, Sanskrit, Russian, etc. This approach seems to be a case of the so-called European ultimate way of thinking, very similar to what happened to French whose order of language units grew more in definiteness, as compared to Latin, in which there could be observed fluctuations in the positions of adjective and genitive.

\section{Authors' contributions:}

Paribok A.V. - analysis, writing the half of the article, developing the basic concepts, formulation of theoretical hypothesis; 
Pskhu R.V. - analysis, writing the part of the text and developing the main concepts of the research; editing and final review of the text;

Zashchitina G.V. - translation into English, writing the part of the text, editing and final review of the text;

Roman L.G. - analysis, writing the of the part of the article, work with primarily sources in Russian and English languages;

Danilova N.N. - formulation of theoretical hypothesis, work with sources in Russian language.

\section{References}

[1] Baker MC. The atoms of language. The Mind's Hidden Rules of Grammar Basic Books. Oxford University Press; 2002.

[2] Mager M, Mager E, Medina-Urrea A, Meza I, Kann K. 2018. Lost in Translation: Analysis of Information Loss During Machine Translation Between Polysynthetic and Fusional Languages. Proceedings of the Workshop on Computational Modeling of Polysynthetic Languages. Association for Computational Linguistics; 2018. P. 73-83.

[3] Merleau-Ponty M. Phénoménologie de la perception. Paris: La Librairie Gallimard, NRF; 1945. $531 \mathrm{p}$.

[4] Pinker S. The language instinct: The new science of language and mind. London: Penguin; 1994.

[5] Smirnov AV. Events and Things. Moscow; 2017. 232 p.

[6] Potter S. Modern Linguistics. A. Deutsch; 1960. 192 p.

[7] Baker MC. The polysynthesis parameter. Oxford University Press; 1996.

[8] MacSwan J. The argument status of NPs in Southeast Puebla Nahuatl: Comments on the Polysynthesis Parameter. Southwest Journal of Linguistics. 1998;17(2):101-114.

[9] Smirnov AV. Mind. Logic. Language. Culture. Meaning. Moscow: Languages of Slavic Culture; 2015. 712 p.

[10] Smirnov AV. Logic of the Meaning. Theory and its Application to the Analysis of Arabic Philosophy and Culture. M.; 2001.

[11] Pskhu RV. Philosophical Sanskrit and Difficult Process of its Russian Translation. Voprosy Filosofii. 2016;(3):80-89.

[12] Pskhu RV, Zashchitina GV, Kholina IM. Bringing Language and Philosophy Together through Linguistic and Philosophical Interpretation of Language Units. Proceedings of 4th International Conference on Education, Language, Art and Intercultural Communication (ICELAIC 2017). Atlantis Press; 2017. P. 369-373.

[13] Pskhu RV, Zashchitina GV, Danilova NN, Kryshtop LE, Kalashnikova LG. Philologist Versus Philosopher on the Translation of the Philosophical Texts. International Conference on Contemporary Education, Social Sciences and Humanities (ICCESSH 2017). Atlantis Press; 2017. P. 61-64.

[14] Paribok AV. On Phylosophical Justification of Heidegger Treatment of Language. Voprosy Filosofii. 2018;(11).

[15] Arnauld A, Lancelot Cl. Port-Royal Logic. Transl. by NY. Bokadorova. YM. Stepanov (ed.). Moscow: Progress; 1990. 272 p.

[16] Abu Rayhan al-Biruni. Selected Works. Vol. 2: India. Transl. by AB Khalidova, YN Zavadovsky. Tashkent: The Tashkent Academy of Sciences; 1963. 728 p. 


\begin{abstract}
About the authors:
Paribok A.V. - Ph.D in Philology, Professor at Department of Philosophy and Culturology of the East, SPbSU, St. Petersburg, Russia (e-mail: paribok6@gmail.com).

Pskhu R.V. - DSc in Philosophy, Professor at Department of the History of Philosophy, RUDN University, Moscow, Russia (e-mail: r.pskhu@mail.ru).

Zashchitina G.V. - Ph.D in Philology, Professor at Department of Linguistics and Intercultural Communication, MSLU, Moscow, Russia (e-mail: jackdawnest@gmail.com). Roman L.G. - Master student at Department of History of Philosophy, RUDN University, Moscow, Russia (e-mail: lily.roman3012@gmail.com).

Danilova N.N. - Ph.D in Philology, Dean of the Faculty of Distance Learning, MSLU, Moscow, Russia (e-mail: danani@list.ru).
\end{abstract}

\title{
Трудности и перспективы параметрической концепции языка
}

\author{
А.В. Парибок ${ }^{1}$, Р.В. Псху ${ }^{2 *}$, Г.В. Защитина ${ }^{3}$, \\ Л.Г. Роман ${ }^{2}$ Н.Н. Данилова ${ }^{3}$ \\ ${ }^{1}$ Санкт-Петербургский государственный университет (СПбГУ), \\ Россия, 199034, Санкт-Петербург, Университетская набережная, 7/9 \\ ${ }^{2}$ Российский университет дружбы народов (РУДН), \\ Россия, 117198, Москва, ул. Миклухо-Маклая, 6 \\ ${ }^{3}$ Московский государственный лингвистический университет (МГЛУ), \\ Россия, 125993, Москва, ул. Тверская, 11 \\ "pskhu-rv@rudn.ru
}

\begin{abstract}
Аннотация. Детально рассмотрены проблемы, поставленные в работе М. Бейкера «Атомы языка. Грамматика в темном поле сознания». Как известно, в этой работе представлена параметрическая теория языков, согласно которой языки различаются, но при этом остаются сопоставимыми. Основанием этого служит тезис о том, что различия между языками определяются «небольшим количеством дискретных факторов, называемых параметрами». Более того, в многообразии языков заметна некоторая регулярность, напоминающая регулярность химических элементов в таблице Д.И. Менделеева. Наша рабочая группа, состоящая из профессиональных лингвистов и философов, подвергла эту концепцию критическому анализу, результаты которого представлены в данной статье, основным из которых является положение о том, что Бейкер, следуя за традицией генеративной лингвистики Хомского, превращает временные процессы в пространственные отношения, не обсуждая последствия этого шага, в силу чего психолингвистический аспект поднятой им огромной темы оказывается невозможно развернуть.

Ключевые слова: лингвистика, философия языка, параметрическая теория языка, язык, параметр языка, генеративная лингвистика, языковое мышление
\end{abstract}

Информация о финансировании и благодарности. Статья подготовлена при поддержке гранта РФФИ № 20-011-00479.

\section{История статьи:}

Статья поступила: 18.01.2021

Статья принята к публикации: 29.03.2021 
Для цитирования: Paribok A.V., Pskhu R.V., Zashchitina G.V., Roman L.I., Danilova N.N. Difficulties and Perspectives of Parametrical Conception of Language // Вестник Российского университета дружбы народов. Серия: Философия. 2021. Т. 25. № 2. С. $340-348$. DOI: $10.22363 / 2313-2302-2021-25-2-340-348$

\section{Сведения об авторе:}

Парибок Андрей Всеволодович - кандидат филологических наук, профессор кафедры философии и культурологии Востока, СпбГУ, Санкт-Петербург, Россия (e-mail: paribok6@gmail.com).

Псху Рузана Владимировна - доктор философских наук, профессор кафедры истории философии, РУДН, Москва, Россия (e-mail: r.pskhu@mail.ru).

Защитина Галина Викторовна - кандидат филологических наук, доцент кафедры лингвистики и межкультурной коммуникации, МГЛУ, Москва, Россия (е-mail: jackdawnest@gmail.com).

Роман Лилия Геннадьевна - магистр кафедры истории философии, РУДН, Москва, Россия (e-mail: lily.roman3012@gmail.com).

Данилова Надежда Николаевна - кандидат филологических наук, декан факультета заочного обучения, МГЛУ, Москва, Россия (e-mail: danani@list.ru). 